\title{
THE THING IN A JAR: Mushrooms and Ontological Speculations in Post-Yugoslavia
}

\author{
LARISA JASAREVIC \\ University of Chicago
}

Several years into the new millennium, Bosnian kitchens excitedly trafficked in a sort of a fungal surplus. Submerged in recycled glass jars, slimy worlds of opaque, liquid hyperactivity oversupplied homes with medicinal brews. Unsealed but covered with gauze - to allow the plump, slippery, fizzy collectives of yeast and bacteria to breathe - the jars were stashed casually in kitchens, among the common pots of African violets or between pots and pans. They sat fermenting next to other invisible fixtures - an old souvenir, a salt-and-pepper shaker. I barely noticed the jars while investigating health and wealth in Bosnia from 2006 to 2007, precisely because they were almost everywhere and so randomly placed. I also missed them every summer I traveled back until, in 2013, I started voicing a persistent health complaint. In response, tea- and milk-based fermented drinks came highly recommended and with my troubles as a password, the obscure jars emerged from everywhere to animate conversations and interactions, pluripotent and therapeutically promising. The jars of the ready-made drink or the starter cultures passed as gifts through neighborhoods, offices, marketplaces, classifieds in the local newspapers and many post-Yugoslav online spaces as therapeutic interventions into health complaints from digestion to high blood pressure, from cancer to stress. Somewhat less reverently, people translated and mixed stories of the medicine's proper name, calling it Tibetan mushroom, mushroom from the Caucasus, Japanese mushroom, kombucha, tea or kefir mushrooms. Some 
were explicitly concerned with the microbiological nature of the cultures responsible for the fermentation, but even among the microbe-savvy, the mushroom and, endearingly, the little mushrooms (gljiva; gljivice), remained the favorite terms.

The casual naming and frequent confusion between tea- and milk-based homebrewed remedies suggest that in popular practice, it was less certain where the mushroom came from and what kind of a thing, essentially, it was. The claims about what the mushroom could do were taken, trustingly, at the word of those passing along the curative gift - and then put to trial in one's own kitchen and diet. Those convinced of its benefits fed it to the near and dear in a loving, meddling, ongoing experiment of care. This care readily reached further away from one's kitchen, for the guts and comfort of those who could not be readily spoon-fed to wellness: strangers who happened to confide their health issues in passing, anywhere, online or in the waiting lines of medical establishments. Those who doubted or had specific questions turned to others for reassurances. In one online post, a woman addressed a kefir forum with sudden misgivings about the milk-fermenting mushroom, which she cultivated and eagerly distributed — "it spreads like mad" — until her husband wondered aloud one day: "Who knows what we are drinking! It looks sickly." Her panicked post affirms a basic knowledge about practical matters - how to care for the milk kefir grains - and admits a keen desire to continue fermenting, if only someone more knowledgeable would confirm the benefits and advise on the frequency of use. ${ }^{1}$

Recommendations about the medicinal jars and instructions on how to care for the mushrooms tie together fermentation and non-commercial circulation, human and fungal connections. "When the mushroom doubles [in volume] we split it and give half of it away," reads the tail end of one online post. ${ }^{2}$ Similarly, the following online announcement cites the remedial properties of home cultivation and gifting dispositions: "I have enough [tea-based mushroom] to share. I noticed some internet sales. That is simply wrong, because these are mushrooms that are passed on, i.e. gifted."3

I begin with fermenting jars to think the effervescence and generativity of what sits inside them. The jars in pantries and kitchens host but barely contain a thing that multiplies further and fast, that brews billions of lively biotic forms, urging the giving onward and producing surplus and waste. Whatever lies behind the translucent glass is unclear, though speculations about its origins and nature abound. The remedy is recommended, while the claims about what it does are personally tried and tested: incorporated into diets and, in time, evaluated with the help of biomedical imaging and laboratory tests or firsthand observations on 
how they make someone look, sleep, digest, or feel. The thing in the jar is known through handling, tasting, and testing. It remains precisely unknown, but it is guessed, imagined, and worked out through varied forms of contact and relation. Wondrous and popular, vague and effective, it urges us to think more creatively about the kinds of things that act and inspire inquiry within the spheres of medically plural circulation and social relation.

\section{THE THING IN A JAR}

This essay is concerned with objects of experiential knowledge and collective speculations. It joins current conversations on the agency of matter, but does so in the spirit of home fermentations, preferring cues from the sites of brewing over the latest terms of ontological inquiries, from object-oriented to neo-vitalist (e.g., Harman 2005; Bennett 2009). In thinking matter, I foreground the question of the efficacy of homemade medicine, emphasizing its varied and unpredictable course, its generativity beyond the medically measurable difference to the signs or experience of illness, while at the same time asking how fermenting cultures, human bodies, and affective associations are substantially formed through popular trials.

The jars peddle a lively, quotidian surplus, coproduced through microcultures' appetites and the popular culture's investment in health and informal exchange. Fermenting and producing medicine at home, economizing, sharing, and caring are concerned with banal, bodily matters: with the gut flora and digestive capacities, with gallbladder secretions, good mood, lubricated joints, and clear skin. Banal efficacies that make life easier and better are highly desirable but impossible to achieve on one's own, especially given the compromised state of postsocialist public and private health care. Medicinal jars, like other informally obtained therapeutics, occasion and depend on shared bodily experience and collective, curative, and intimately transactional practice. Someone's affliction or bodily discomfort mobilizes concerned others around practical tasks of recommending and procuring the remedy, instructing on its applications and cultivation, and exchanging tips and observations.

The mushroom jars, therefore, are phenomenally generative, and not just of fizzy fluid and fermenting agents. They foster and ferment bubbly zones of connection and relational innovation, especially since their vagueness begs questions: How best to relate to the mushroom? With whom to relate via the mushroom, and how? They raise such questions in a Bosnian state that has been constitutionally and electorally trapped within the politics of ethnonational essence 
since the 1995 Dayton Accords ended the genocidal war by sanctifying distinctions between ethnic Serbs, Muslims, and Croats. What is more, the mushroom remedies casually traverse the polarized borders of former Yugoslav states as simple items in an informal economy of gifts, medicine, and advice that negotiate logistical hassles rather than ideological hurdles.

The mushrooms, moreover, are not merely handled: they variously inspire and direct forms of contact, circulation, and speculations on nature and relation. The slippery, pink blob that passes in sugary tea and the grainy clots that curdle milk embody obscure potencies that flow through recycled jars, generous hands, and mixed stories of origins and substances while altering the encountering matter, from visceral to domestic, from virtual to spatialized. The mushrooms' thingly obscurity and patent exuberance, their puzzling appearances and famed performances, are anything but incidental to this subtle sort of efficacity.

Lately, things have exercised the scholarly imagination. Some thinkers are interested in things' very thingliness, which remains beyond the grasp of human thought and experience, a metaphysical given, if obliquely so (Heidegger 1971), an object of an "alien phenomenology" (Bogost 2012), or a "hyper-object" (Morton 2013): an engulfing presence at a mind-boggling scale. Other scholars attend to how things are and how they act (Harman 2005; Latour 2005), how they come into being and pass away (Daston 2000), what force resides in or moves through them (Ingold 2006; Bennett 2010), who decides whether they are at all and what power issues from such deliberation on the material design of the world (Langwick 2011; Stengers 2010; Povinelli n.d.). Significant theoretical differences aside, scholars of things have collectively exposed the extent to which non-humans compose the social worlds from which humanist political thought and democratic practice consistently exclude them, or else include them reductively, as dumb utilities or accessories. Moreover, thinkers of things have proposed we consider, sometimes shaming us into doing so, the various political achievements of stuff. From the political ecology of things (Bennett) to the parliament of things (Latour) to cosmopolitics (Stengers), the new materialisms affiliate with divergent political philosophies that are attuned to what matters potentially and what moves laterally_-forming knowledge and experience — at least as much as to what is actually itemized on the agendas of formal politics. Collectively, the turn to things adds fuel to thinking politics, and indeed to dreaming of change, in a postfoundational mode, collecting the vibes of emergent energies, converging dispositions, and new media and mobilizations across the predictable lines of affiliation. 
Such political propositions frame a compelling volume edited by Bruce Braun and Sarah Whatmore (2010). Political Matter troubles the reductive idea of "intransigent," reactive objects to focus instead on the elastic, eventful, active, and affective qualities of various "things that matter" - from rubbish to plastic to metal. On behalf of the featured authors, Braun and Whatmore call for a more robust engagement with materiality while voicing a shared question: How does stuff ground, pervade, and transform political life, which always already includes more than human collectives? More specifically, the contributors to Political Matter are attentive to the sway of stuff taken for granted that infiltrates the air as much as political agendas, that inserts itself snuggly in the midst of social gatherings. They find powerful agents at work in the midst of everything that humans arrogantly consider their own business and attune to the powers that furtively flirt with each accessorized subject, one earphone at a time. Put simply, the authors assume that being and being social are the primary political concerns of civic life that have never been strictly nor solely human. Recognizing plural and shared fields of consequential action makes for a first step in reconstituting public relations and responsibilities.

I take to heart the volume's accent on forcefulness and the participation of all sorts of seemingly random and easily missed things, but with the mushroom in sight, I finally hesitate to call it political: because, I fear, other kinds of practical significance would be blanketed by the muscular connotations of a generalized power and because highlighting the politics of matter would hide equally transformative and subtly constitutive potencies at work through (medical) knowledge and (health) experience. Moreover, while the contributors to Political Matter are mostly focused on technoscientific and industrial objects or items of capitalist consumer economies, ${ }^{4}$ the mushroom constitutes a life-form thriving in and fomenting terrains of knowledge that only occasionally confer with science. They are mostly otherwise occupied. They busy themselves with the practical and experiential sense more fitting for the tasks of cooking and home treatment, more in tune with informal and etiologically plural medical advice. The mushroom forms part of the therapeutic lexicon often critical of biomedical and pharmaceutical authority, though inconsistently so, skeptical of industrial food technologies, and dashingly inventive and improvisational. This essay thus wonders about the efficaciousness of matter on bumpier grounds, where scientific controversy mixes with common sense and wonder, where concepts have never quite achieved the consensual status of fact — which Bruno Latour (1988) calls a "black box" — but are instead open and bursting with colorful propositions, speculations, and claims. 
Unlike Braun and Whatmore, I am not particularly frustrated with the scholarly fixation on the thinking-feeling human, but rather interested in how mushrooms shape and are formed by the explorative and experimental imagination. I describe processes whereby the reality of a remedial body is linked with ingesting and inventing, trying and knowing, handling and wondering about what the acting and affecting thing might be. In other words, While Braun and Whatmore are interested in what things do, the mushroom, I suggest, urges us to think more about the nature of what is, especially when the thing remains elusive and open, and its definitions propositional, partly fictive, enchanted, and playful — but no less influential for that.

As I will show, it matters that the mushroom is not really or only a mushroom. Nor is it simply a curious vernacular shorthand for tea and milk probiotics. The mushroom is a preferred ontological speculation about a liquid, unstable thing on the brink of exceeding, multiplying, spreading, and sporing; a form slippery to grasp that invokes conflicting properties and inspires wonder; and an aliveliness unlike human or plant, and synonymous with fortuitous, found, and gifted. The mushroom translates imprecisely but earnestly between strange lifeforms that alter their allies, hosts, and consumers. It tasks its cultivators and consorts with courting interspecies, interethnic intervention, except that neither species nor ethnicity form a part of the fermentation vocabulary. Speculations are spontaneous, sometimes explicit, and selectively informed by the established rubrics of life and relation, and they are rarely intimidated by the received or disenchanted criteria for what counts as real, fictive, and possible. Ontological speculations are popular inquiries that point to the unclosed, underdetermined state of the matter, be it a fungal-yeast collective or human viscera, allowing outlandish interactions between ailing bodies and promising cures. Inquiries prime and take cues from the matter, giving rise to the possibilities that an event may take place outside the realm of a reasonable assumption.

The essay proceeds by situating the jars within the tradition of domestic food and medicine in postsocialist circumstances. I spend time describing the terms of practical knowledge that handle and evaluate the mushrooms according to the vital signs of difference that these remedies promise to compromised bodies. The circuitous channels of banal power point to plural efficacies and causalities of things and suggest that we consider the mushrooms' and the mushroom growers' receptiveness to varied forms of handling and explanations. Seemingly confused therapeutic practices have real effects but a different grasp on medical matters, both the suffering body and the medicinal object. The rest of the essay 
fleshes out, bit by bit, the natures and forces perched in the jars that are superabundant, irreducible to a single explanatory frame or therapeutic efficacy, leading to many points of origin and suggesting multiple and undecidable forms of proper contact and care. I show how the surplus that issues from the jars practically contributes to the popular imagination about the mushroom and to the tender, connective feelings it stirs in and among others. The jars guide collective action in the direction of (non)economic value and medical intervention into subjective and shared bodily experience under the conditions of a perceived health emergency and diffused medical expertise.

\section{POSTSOCIALIST HEALTH, HOMEMADE MEDICINE}

The medicinal thing at hand is related to the agents of fermentation that have attracted attention among global health-conscious, medically curious publics as well as researchers of traditional medicine: kombucha and dairy kefir. ${ }^{5}$ The transnational careers of probiotics and home-fermented drinks offer a number of parallels with gljiva itineraries, but the postsocialist and post-Yugoslav conditions of the jars' handling urge a more hesitant comparison between contexts of practice and an ethnographic investigation of what the jars in Bosnia enclose and do. The regional markets for probiotic drinks and dietary supplements are relatively small, especially in Bosnia, and home fermentation takes place largely outside the probiotic frames of reference and within a longer tradition of homemade medicinal meals. The mushroom here thrives under the conditions of a quiet, ongoing public health-care crisis.

The World Health Organization (WHO) describes Bosnia as challenged by unequal access to health care. ${ }^{6}$ Seventeen to thirty-five percent of the population remains without the health insurance that provides access to public health facilities and a few subsidized pharmaceuticals. As elsewhere in postsocialist Eurasia, even the insured rely on payments and personal connections to expedite the provision of care and to secure medical attention by whatever means (see Rivkin-Fish 2005). The WHO report on Bosnia underscores regrettable institutional fragmentation, inefficient service delivery, and financial unsustainability. At ten percent of the country's GDP, according to the WHO, public and out-of-pocket expenditures for health care lie above the European average in one of the region's poorest states. Bundled together by the WHO under the rubric of "complex political environment," these three issues constitute for the principle impediment to Bosnia's health development. The report's euphemism refers to the constitutional arrangements that split Bosnia into two administrative entities, the Serb Republic 
and the Federation of Bosnia and Herzegovina, and within the latter, further into two entities, ten cantonal health ministries, and municipal institutions with unclear divisions of labor, overlapping authorities, varied health benefits, and steep operational costs.

The administrative and legal framework that emerged from the difficult peace negotiations of the 1990s has been amply discussed and criticized (see, e.g., Bougarel, Helms, and Duijzings 2007; Kurtovic 2013), not least because it locks the state in a tripartite ethnic scheme. And while the ethnonational paradigm is certainly making Bosnian lives more difficult, it does not overdetermine them nearly as much as it does policy or scholarly analysis of Bosnia. Scholars interested in health and medicine have been preoccupied with forensic investigations and war trauma, issues that are, unsurprisingly, moored in the ethnonational rubric (e.g., Wagner 2008; but see Jansen, Brković, and Čelebčić forthcoming). What eludes these studies as well as the WHO becomes apparent when one looks at medicine sideways, attending to places and practices that shift a sense of therapeutic care and efficacy beyond strictly professional or pharmacological action.

Since 2006, I have been visiting clinics, pharmacies, health centers, and alternative and traditional medical practices across northeastern and central Bosnia, interested both in how people are collectively imagining, pursuing, and waiting for proper medical attention and in the kinds of health care they receive. I learned that while searching and waiting for treatment, people tirelessly discuss therapeutic options and each other's symptoms and tests, swap complaints, advice, and treatment histories, evaluate health practitioners and medicinal brands. Their therapeutic repertoires commonly include items of more global fame (from noni juice to royal jelly) and the stock of homemade or homegrown (domaće) substances: those that are collected, cooked, fermented, dried, and mixed at home, in a country house or in someone's yard, often over an open fire. By 2013, the mushroom jars had lost the currency of the latest fad and entered into the inventory of domaće. While Yugoslav modernist socialism invested in public health and hygiene, in pharmaceuticals and industrial foods, it never quite compromised the venerable standing of domaće staples, or of folk medicine more generally. Cookbooks, women's magazines, and domaće producers circulated recipes and advertised the health benefits of fermented and homemade foods, while widely read herbalists made little distinction between meals and medicine (see Sadiković 1988; Mijatović 1982; Pelagić 1972).

Domaće is not a kind of gustatory nostalgia that, according to Elizabeth Dunn (2008, 246-48), begrudgingly compels Georgians to can vegetables, both 
because of distrust in the postsocialist food industry and to indulge in cravings for pickled vegetables once supplied by the Soviet state. Considering the high rates of foodborne botulism and a public health emergency, Dunn (2008, 255) regards the pickled jars as sites abandoned by the state and capital and as zones of unpredictability and danger. Like Georgians, post-Yugoslav producers of domaće often doubt the state's food quality control, but they equally mistrust the confidence the state and industrial capital have in mass-produced foods with a long shelf life and a brief consumption span. Moreover, the domestic production of food and medicine regained value in Bosnia during the 1990s wartime shortages, when domaće recipes were excavated, retouched, or ingeniously invented for anything from herbal shampoos to coffee substitutes to meals from weeds. Domaće, however, is not a mere survival tactic but a robust preference for the handmade, preserved, natural (prirodno), and perishable.

Melissa Caldwell $(2004,2010)$ finds similar pleasures attached to summer garden foods and foraging, especially for mushrooms, in postsocialist Russia. Caldwell (2014), however, finds Russian dietary ethics rooted in an ecological nationalism that attunes citizens' bodies with the ideas of Russian mother nature and ties rural escapes to state-oriented engagements. Similarly, in postsocialist Bulgaria, the national flavors certain foods (Yatova 2013). As Japanese dairy market campaigns designate Bulgaria as the homeland of yogurt and their images repatriate to that country, Maria Yatova's interlocutors taste the sourness of dairy as the authentically ethnobacterial quality of local fermenting culture, Lactobacillus bulgaricus. In short, Yatova argues for the bacteria's symbolic capacity to feed and form Bulgarian ethnonational memories and myths. In both postsocialist contexts then, the political careers of homemade foods seem to have particularly ethnonational orientations.

In North America, on the other hand, food and value entanglements shift toward concerns with safety and sanitation, as well as to artisanal and do-ityourself responses to industrial foods. Not surprisingly, microcultures here exercise different associational stunts, which Heather Paxson (2013) captures under the rubric of "microbiopolitics"_regulated and contested relations between microbes and humans that mark the consumption as well as the production of foods and tastes. Within the pasteurized food culture of the United States, artisan cheesemakers cultivating the microbial complexity of their cheeses while sorting out, meticulously, the good bacteria from the potential "biohazard" (Paxson 2008, 33). In contrast, home fermentation occupies a more precarious position in North American food politics. Radicalized by food regulations and marginalized by the 
mass appeal of antibacterial reason, home fermentation is an ideological stance. Sandor Katz (2003, 2006, xiv) includes live-culture foods within a range of unorthodox, sometimes fringe, food activisms whose countercultural potential he increasingly appreciates as his writing moves from practical guides on wild fermentation to a description of broader practices of "culinary mutiny," from seed saving to scavenging, which he collectively terms America's underground food movement. Paxson (2008, 37) reads Katz as an oracle of the "post-Pasteurian" trend, which owes much to lessons on hygiene and bodily defenses while it fashions forms of self-care around collective, biologized identities.

A comparative gesture here is multiply instructive, showing that regional trends and global regimes are inevitably implicated in local affairs, but never predictably so. Put simply, neither biopolitics nor ethnopolitics neatly contain the mushroom story. Domaće foods, and the mushroom jars in particular, circulate a medicinal rather than an ethnonational value. Moreover, it is not the microbes but, rather, the mushroom that organizes fermentations, that materializes and banalizes oppositions to the industrial and pharmaceutical commodities, and that engenders broader connections beyond fringe or national solidarities. People carry out comestible trials with the flair of seasoned cooks or spontaneous inventors, encouraged by countless examples and trusting collective common sense. Brewing within the jars is an acute sense that the history of the war and the postsocialist present have altered local bodies and pluralized afflictions, thus calling for revised and reinvented therapeutic responses. I whittle a critical point from popular inclinations toward medical experiments and stray away from the language of ethnonational symbols and of microbes to the more promiscuous descriptions of fermented drinks.

\section{PEOPLE CALL IT THE MUSHROOM}

Online venues were often determined to get to the heart of the fizzy medicinal matter. Some authors differentiated between tea and milk fermentations, while emphasizing that there was no mushroom in kefir, kombucha, Tibetan mushroom, Japanese mushroom, the mushroom from the Caucuses, or "whatever else people like to call it." Instead, they pointed to the symbiotic composition of the cultures responsible for herbal and dairy fermentation and further catalogued their micro-organic and biochemical properties. References recycled a handful of international academic papers in English on Tibetan mushroom and kefir. Nonetheless, even the online author who pedantically listed dozens of resident species and subspecies of yeast and bacteria in kefir ended the text with a 
reference to the "little mushroom :D." A smiley signs a playful invention - the mushroom, it turns out, is what people like to call it.

On the other hand, health circles on the ground seldom worry about the proper name for mushrooms. The cultivators' attention is nearsighted, fixated on familiar and immediate links in the broader and convoluted logistical networks that handle popular medicine. The vernacular knowledge that frames homemade medicine, however, is extensive and curious. It registers the certain ease with which the tradition of domaće embraces the new and the exotic, entertains seemingly improbable suggestions, and fans a more general curative and economic significance of domestic production. One family I visited on the outskirts of Tuzla, a northeastern Bosnian town, traced their fermented medicine to a hairdresser. A jar of black tea with the mushroom, translucent layers floating like a trapped jellyfish, was among twenty remedies in this family's pharmacy that Mina and her husband, Hariz, fetched to show me one afternoon. The surface of the garden table filled with herbs and weeds, freshly plucked or dried in the storeroom; a jar of gluey cream for bone pain (crushed aspirin, gelatin-based soap, and homebrewed brandy); concoctions of herbs, seeds, and honey; fruit and flower infusions and vinegars. Mina's mother-in-law had passed along many recipes. Instructions on how to make the aspirin-gelatin-alcohol cream came from the neighborhood car mechanic to whom Mina's husband had complained, in passing, of incapacitating and mysterious leg pain. Whereas other herbal remedies had failed, the cream marvelously restored Hariz's mobility and rid him of pain, inspiring his orthopedic surgeon to analyze a sample and interpret the mechanics of its action. The couple was thrilled to report this formal medical interest in and vindication of folk remedies. Mina's hairdresser brought the mushroom after hearing the neighborhood talk of her upcoming breast surgery appointment. Other remedies were simply the common stock of knowledge that, supposedly, "people talk about [pričaju ljudi]" and "everyone knows [svak' zna].”

The home production of medicine saves money and assures the highest medicinal quality of ingredients: "It's better than chemistry," Mina says confidently. One often hears such misgivings about synthetic medicine in Bosnia, although pharmaceuticals are commonly self- and overprescribed. Except for an occasional tranquilizer and a daily dose of heart medicine, she disregards her doctors' prescriptions and autonomously manages her blood pressure and cholesterol levels, treats her headaches and chronic stomach aches, keeps her skin youthful and cleansed. Moreover, she has revitalized her liver, minimized her surgery scars, regulated her bowl movement, and kept her spirits up through two che- 
motherapies, a hysterectomy, a duodenum and heart surgery, as well as a partial mastectomy. Given her health record and the fact that she has had recurrent cancer since 2003, Mina has been a regular visitor at health centers and the regional clinic. She thanks home remedies, however, for prolonging her life beyond her doctors' expectations.

It is the oral orientation of popular medicine that invites collective interventions and improvisations that adjust recipes according to the user's taste and particular bodily responses. In the words of Cvita, who advertises a surplus of kefir and tea mushrooms in the municipal yellow pages, "you have to monitor how [the mushroom] affects your health. Perhaps you need to start with a shorter fermentation ... the effects are still there but more subtle." Cvita reports that the tea mushroom and milk kefir regulated her cholesterol levels and curbed her appetite. Mina, conversely, thanks the tea mushroom for regulating her digestion after her hysterectomy. Another woman, Ismeta, praised the tea mushroom for its calming effects — "it sooths the nerves" — but noticed that, sadly, it made her gain weight.

The sheer variety of bodily responses that the mushrooms produced did not bother the users, who expected the medicine to affect them singularly and considered the cure to reside not in the predictable pharmacological formula or dosage but in the fortunate coincidence between the irreducibly singular patient and a particular medication. It is perhaps no surprise that a number of home and herbal remedies come recommended with vague statements such as "it cures everything." Considering that Bosnians otherwise provide minute descriptions of their medical routines and that each remedy is promoted with reference to exemplary cases of its efficacy, vagueness regarding the mushroom cannot be dismissed as typically pragmatic inattention to detail. Rather, practitioners of popular medicine know and "monitor" experientially, collectively, and with the aid of diagnostic technologies, a kind of bodily being that is particular and unpredictable, continuously baffling, and promisingly responsive to different forms of care.

\section{RESPONSIVE BODIES}

Folk optimism about the mushrooms indexes a hands-on familiarity with the body, worked out through trials of natural, traditional, and home medicine. Such medically experimental communities gather elsewhere and particularly around chronic and poorly understood conditions or unorthodox therapies. Chloe Silverman (2012) describes joint pursuits of North American parents and physicians allied in their search for alternative understandings of autism. The members of 
DAN! (Defeat Autism Now!) conduct and discuss home-based trials of unconventional therapies. Home treatments, Silverman (2012, 373) suggests, are cautious and involve reading anything from children's faces to feces for subtle clues of physiological and behavioral changes.

The same holds true with mushroom gatherings. Nothing is too trivial to mention, guts are spilled when listing problems - constipations, discharges, bad odors, skin rashes - and no condition seems untreatable. "People, have no doubt, this mushroom is for real," ${ }^{\prime 8}$ says one post on Coolinarka, a self-declared online food community. The writer demonstrates "the real" with blurry ultrasound images of gallbladder stones nearly disappearing thanks to the Tibetan mushroom. The testimonial advises a reader to "think twice before [deciding on] surgery." Coolinarka is registered in Croatia but, as many web venues in the Bosnian, Serbian, and Croatian languages, it attracts users from throughout the ex-Yugoslav states. Like DAN!, those advertising the mushrooms speak the language of care, except that they advertise its benefits to no particular diagnostic affiliation.

Comparable are also multiple scales of efficacy: some consumers are perfectly content to report finer transformations, such as feeling energized or refreshed, while others wish to account for these precisely. One parent's endorsement of milk kefir reads: "Our child is drinking it and the results are notable in the blood count, c-peptid blood test, and the child's entire biochemistry."

But here lies a significant divergence between DAN! and the mushroom cohorts, between Silverman's and my own analytic ambition. To avoid charges of credulity and charlatanism, the North American parents and doctors indignantly translate alternative and home treatments into the language of biomedical procedures. DAN! members' reflexivity perhaps informs Silverman's (2012, 370) disclaimer: "I do not want to suggest a process of indoctrination or induction into 'irrational' nonscientific belief systems, but rather a secular community that is acutely aware of the social context of systems of reason, and difficulties inherent in translation and proof." Rather than concede to the normative expectations of rationality $(=$ allopathic $=$ secular $=$ credible $)$ or presume that affiliation with something non-scientific implies a belief in lieu of access to legitimate evidence and a clinical trial that can never be had, the therapeutic repertoire of the mushroom prompts a second look at the notion of medical efficacy. To most mushroom cultivators, biomedicine speaks the official language of reason, but they nevertheless question its competence and wonder about the limits of its arbitration outside of pharmaceutical and surgical interventions. People rarely chafe at the fact that the value of any medicine, be it herbal, pharmaceutical, or homemade, 
is figured out not in the scientific trials that guarantee a straightforward relationship of cause and effect, plus an expected surplus of adverse effects, but gradually and circumstantially during a personal treatment where multiply causal forces are at work and sometimes at odds with each other. Causality is often a sort of matchmaking, whereby biographical dispositions, the imagination, and quotidian habits, as well as numerous, variously positioned, deceptively small and trivial agents - say three leaves of sage freshly plucked from a garden and chewed on an empty stomach, first thing in the morning - play out in an infinite number of singular cases of therapeutic recovery or protracted failures. Likewise, efficacies are experientially proven even if they remain formally or biometrically unintelligible and open to numerous and fantastic interpretations. On the other hand, given the formal sway of modern medicine, it is no surprise that popular health experiments, including with the mushroom, earn some stern commentary. For instance, in response to buoyant claims about the mushroom available on the forum doctor.rs, one Dr. Ivica provides a mock list of the drink's pluripotent therapeutic benefits that starts by singing praises and swerves off into unlikely and unrelated uses and effects: "It removes stains, eliminates odors, polishes wood floors. ${ }^{10}$

Dr. Ivica's edgy joke and the DAN! members' self-consciousness bring to mind Isabelle Stengers's (2003) thoughts about the particularly "polemical accent" on rationality in medicine, which she traces to the emergence of the experimental method as the authoritative statement on illness and its proper treatments. Medicine, Stengers (2003, 14-16) suggests, is stalked by the figure of the "charlatan," with a long lineage including Dr. Mesmer, whose magnetic-fluids therapy was famously included in medical trials in 1784 that were to model a distinction between medicine proper and putatively improper cures, which worked, but for "the wrong reason." In short, the efficacy of magnetic fluids could not be isolated and was dismissed as a "power of the imagination," a power worked up between a compelling charlatan and his allies: the impressionable bodies (Stengers 2003, 15, 23). The same power has been since controlled for in clinical trials that aim to turn bodies into "reliable witnesses" for a rational medicine's predictions under the conditions of an experiment. Stengers (2003, 25, 29) argues that "there is nothing mysterious or spiritualist in supposing that a living body may not satisfy experimental requirements," since beings irreducibly embody imaginative, meaningful potential and so cannot ever "authenticate the 'real doctor' as against the 'charlatan." She predicts “a radical disjuncture” between evidence-based medi- 
cine, at war with lay irrationalities and charlatanism, and sites "where it is a matter of curing rather than proving."

Instead, my ethnography finds some fungal spheres where the polemic is unsettled or informally resolved through partial translations, where lay publics are invested in turning their bodies into evidence via biomedical measures or imaginative technologies. A body's bold responsiveness to unpredictable, subjectively experienced, collectively praised, curative things is made exemplary through narratives and their circulation with whatever remedies are put on trial. Significantly, promising cures are never strictly medical objects, but things therapeutically cultivated, preserved, and charged in the course of (non)economic circulation and redistribution.

\section{FUNGAL PRESENT}

The mushrooms' efficacies have much to do with the therapeutic economies that the jars presume and invigorate. This is another clue about fungal nature that I picked up in the field, not least by following an advertisement in the municipal yellow pages for a surplus of "tea and dairy mushrooms" and, with the help of my older sister, found Cvita. Cvita gifted her tea culture but told us, apologetically, that she usually takes whatever money people are willing to give in exchange for the kefir grains. My sister gave 10 konvertible marks (around \$7) and, after we left, protested: the advertisement read "mushrooms to give"; "those things" should not be sold. Cvita, a retired kindergarten cook, received both the tea and the dairy mushrooms as gifts from her sister, a migrant care worker in Germany who in turn got them for free from her employer, an elderly lady. Cvita produces tea and dairy kefir for her daughter and has passed the gift of mushrooms on to all her daughters' colleagues, physical therapists working in a public clinic. Put simply, the mushrooms circulated to and from Cvita through multiple spheres of exchange: sometimes a gift and other times a tentative commodity, given without a price, for the present of "however much" money.

Even the multiple and conflicting histories of the mushrooms written on the Internet converge at the mythical point of departure, which is a present. Tibetan mushroom is said to have arrived in Europe from Russia as a gift; to have traveled from India or Tibet, with a German (sometimes Polish) professor whom Tibetan monks cured of grave liver illness (sometimes liver cancer) and dispatched with a bacterial gift. The kefir grains are sometimes traced to a Caucasian legend of the Prophet's gift. More than one article shifts geopolitical coordinates of generosity to draw in the unlikely figure of Ronald Reagan, retired and undergoing 
cancer treatment when, the story goes, he received kombucha from the Japanese government. ${ }^{11}$

The gift is incorporated into the very nature of probiotic cultures. Whatever else it is, the mushroom is giving. Before launching into "more precise, microbiological descriptions," one article introduces kombucha as "the mushroom that is selflessly shared." ${ }^{12}$ Both tea and dairy mushrooms are described as life-forms that reproduce themselves while producing a boundless surplus (višak) whose management becomes an explicit concern for online and other collectives. Grounded in the region-wide economies of debt, limited liquidity, informalized and irregular employment, minimum pensions and depressed wages, those attending to health and life cultivate vital surpluses and handle it lavishly, not as a nostalgic form of socialist public property but as a postsocialist revolving gift that was never owned so much as received to be redistributed. The mushrooms arrive to engender excess not entirely due to the labor of their hosts but owing to their own fecundity, their ferocious penchant for being (more). Mushroom growers steer this surplus away from monetary exchange. Sites devoted to milk kefir issue solicitations, such as: "Is there anyone who has a surplus to gift? I am from Belgrade." "If someone has surplus, please let them share. I am from Sarajevo."13 While each post locates the offering or a request onto a map that simultaneously flags geographical proximities and political distances between, say, Belgrade and Sarajevo, the capitals of Serbia and Bosnia, they seem to be read in mostly logistical modes. Responses are followed by further arrangements, to pick up, drop off, or send via an intermediary batches of live cultures, or to mail dried kefir grains to addresses throughout post-Yugoslav states.

\section{BOUNDLESS}

Advertised with the gift is a tacit predicament of hosting a mushroom whose procreative ambition exceeds one's relational resources. Whatever else it is, the mushroom is a kind of a thing that is too much, that grows madly. One post issues from the threshold of an imminent fungal oversupply: "They reproduce so fast that soon you'll have enough to feed the entire town!" while another publishes the moment after the gifting capacities have been exhausted: "I have run out of people to gift but I would feel sad to throw [the mushroom] away." ${ }^{14}$

Medicinal surplus turns into waste because of one's own social limits, the ability to extend influence far enough and long enough to accommodate the booming biotic aggregate. Some online cultivators are explicitly concerned with preserving the liquidity of the mushroom, so as to prevent the priceless but 
economical and "super" medicinal domestic remedy from disappearing; "it would be a shame." ${ }^{\prime 15}$ Others are unnerved by the mushrooms' evident aliveness. One woman spoke to me of throwing kefir grains into a stream, and the memory sounded a sense of failure years later. Her turning to the stream, instead of a trashcan, resonates with a wider resistance to dumping the mushroom, nesting ethical concerns in affective registers: "I have a surplus but have no heart to throw it away." Or, "I can send it if anyone wants it; I would be sad to have to murder them, i.e., trash them." ${ }^{\prime 16}$ Online venues thus become a mode of achieving what anthropologists of the gift, following Nancy Munn (1986), understand as a spatiotemporal extension of one's otherwise limited, embodied reach, except that here the expansion of one's influence responds to the vital demands of the bacterial-yeast, fictively fungal collective. Gifting announcements effectively seek human recipients to present to the mushrooms. In both chat rooms and by word of mouth, a Kula ring of sorts is established to peddle the mushroom jars, spreading their fame and rolling out the spirit of this medicinal gift.

A spirit indeed: of mimetic generosity inspired by the superabundant form, trying and potentially exhausting [the] humans; of domestic ventures in nourishing, bottling, delivering, and mailing biotic associations to others. Whatever else it is, the mushroom is spirited, invigorating curative flows. Kefir fans are not entirely abandoning industrial food or commodity mediations, but in the service of the stunningly alive and generative fungi-bacterial populations, they valorize non-capitalist common sense. They do so regularly from within the virtual domains of corporate capital. Coolinarka, so vigorously involved with the mushroom, is an online subsidiary of Podravka, a Croatian food giant with transnational ambitions that grew out of Yugoslav pedagogies of socialist consumption. The mushroom here feels at home, although the logic of domace is at odds with Podravka's line of instant soups or its famous brand of seasoning — Vegeta — which is irreplaceable in dishes throughout the ex-Yugoslav region, packed with monosodium glutamate (MSG) and a touch of historical flavoring, sedimented, a spoonful at a time, in the course of televised episodes of Little Secrets of Great Kitchen Chefs on socialist TV. Commodity, too, seems to mushroom: it overgrows, discreetly and indiscriminately, the quotidian terrains on which other ways of being and exchanging thrive.

However, it is not merely a socialist memory or lapses of transitional economy that allow the mushroom to grow non-commercial expectations: an online search for kombucha, Tibetan mushroom, or kefir grains in English, Italian, or Spanish will also yield gift offerings. ${ }^{17}$ The gifting announcements speak to a 
broader viability of the fungal present, renewed in the acts of cultivation and sustained through gifting dispositions employed to distribute and exhaust the surplus, at a hurried pace and toward indirections that make the calculus of reciprocity neither practical nor equitable.

\section{ACCIDENTAL AND WONDROUS}

The mushroom thrives under the conditions of amateur handling. Whatever else it is, the mushroom is a contingent medicinal thing. It arrives with microbiological and social traces of its previous hosts. It dwells, resonant with the everchanging microclimates of its surroundings. People report its reactions to humidity or noise. It changes in discernable ways - the drink becomes more sour, fizzier, thinner, or gooier, sometimes infested with worms. The tea mushroom can turn sluggish, tend toward the bottom, grow long whiskers, or change its pink body pleats for boggy browns. The kefir grains relax, turning flaccid and soupy. And experienced palates detect many more imperceptible but somehow consequential alterations or imagine them to be at work when the drink is served, imbibed, or when cultures pass onward. Instead of the infectious disease that Elizabeth Dunn, ever an ethnographer as well as a consultant for the U.S. Centers for Disease Control (CDC), traces to home canning in Georgia, an undecided contagion is at work in the Bosnian kitchens, a metaphysical sway swirling with the gift, vaguely and indeterminately, energizing the already promising capacity of the gummy clusters and their restless fungal, bacterial, and cellular resident worlds, foreseeing biochemical blasts in the encountering bodies.

The accidental is precisely the medicinal. For cultivators like Cvita or Mina, home medicine means taking special care with the ingredients and patiently waiting through the fermentation - sometimes up to five days or a few weeks - while relying on the unknown potencies of the mushroom to enliven the rest. Some advocate wild fermentation in the idiom of probiotics, claiming that pasteurization disrupts the spontaneous and secondary fermentation and that store-bought products circulate a reduced and controlled bacterial stock. Many online authors emphasize that the symbiotic bacterial-yeast composition of the home-cultivated mushroom is a mystery, found nowhere in nature and impossible to reproduce in a laboratory.

The value of the accident is more generally appreciated among fans of fermentation, be they in ex-Yugoslavia or in North America, and most vividly praised in the writings of Sandor Katz. Katz (2003), who has been on antiretroviral drugs for years, is especially fluent in the microbiotic and biomedical lexicons, but he 
also pitches the relationship with microbes in terms of transformative magics and mundane wonders. He professes a fermentation fetishism. Citing Webster's definition of fetish as anything "supposed to posses magical powers" and drawing on his cooking practice, he celebrates low-tech, primitive kitchen techniques as ancient rituals and credits non-experts with awesome powers. Fermentation is an irresistible, gentle force, the fetishist writes, that slowly makes a difference in the ingredients, in consuming bodies, and in the wider ecology of relationships. He presumes that his readers are apprentices and encourages them to connect to the magic of the natural world, to trust “your instincts - you don't need chemical analysis to tell whether food is healthy" (Katz 2003, 7). Such language, no doubt, can make a cautious anthropologist wary of romantic ideas about magic and instinctive knowledge. With public health concerns in mind, Paxson (2013, 2) also worries that the post-Pasteurians tend to "exaggerate the natural goodness of microbes grown in the wild."

The North American soft drinks industry, which has capitalized on the probiotic trend, is gingerly dancing between Katz-style fetishism and antiseptic public health policy. Kombucha Wonder Drink and some of its competitors develop poetic narratives analogous to the mushrooms' Internet histories, tracing their beginnings to accidental discoveries of secret knowledge in ethnic places, far away, gifted to the companies' founders, who brewed it at first in their own kitchens. ${ }^{18}$ Nonetheless, Kombucha Wonder Drink clearly advocates pasteurization, choosing sides in the microbiopolitical controversy over controlled versus wild fermentation. ${ }^{19}$ Designated by Beverage World Magazine as the "breakout brand" of 2013, Kombucha Wonder Drink wants to dispel the "biggest misconception" that kombucha is either curative or mushroom-related. Invoking an unnamed authority ("a biologist" who "studied extensively"), the trendy business ventriloquizes science and responds symmetrically to lay skepticisms of science and industry: there is no scientific basis ("no evidence," "no original research") for kombucha's reputed health benefits. Promoting something he calls "real-speak," the company's cofounder nevertheless wants to keep wonder as part of the brand's identity, which is "aspirational — who doesn't want to ponder the promise of a 'wonder drink?'”for as long as all are clear that wonder is not "a magic cure-all."

Rooting the brands in amateur wild fermentations, denying the medicinal or fungal nature while invoking "an elderly woman's secret," and proliferating vague statements on the tea's "restorative effects" and "acids," "tickling" with a promise that "something magical is about to happen," the company participates in popular enchantments but does so in a supposedly reasonable, disenchanted 
manner. It gains critical distance and commercial value from wonder by settling on a scientific measure ("no evidence") for what there might be in the fermented tea: nothing vaguely medicinal but acids that feed into "our normal energy producing metabolism" and, possibly, increase energy and improve digestion. Anthropologists who still believe in the appeal and salience of magic - the analytic we so readily abandoned - could savor the charmed production of ambivalence and confidence in the corporate, spellbinding "real."

In Bosnian kitchens, conversely, wild fermentations are brewing ontological speculations on fermenting agents and on cultivating and consuming bodies. Since home trials have inspired me with confidence that dietary experiments are often effective or adjusted, but in any case attuned to multiple causalities and therapeutic possibilities, and that experience is a trustworthy therapeutic guide, my approach to popular enthusiasm for fermenting mushrooms is less cautious than curious, indeed excited, about the nature of the thing that compels wonder-from Bosnia to North America.

\section{SUBSTANTIVE SPECULATIONS}

Throughout Bosnia, fermentation and the circulation of remedies in a jar thrive in the shadow of a mushroom, gljiva. Typically a conditional sort, growing wildly at random places, given the season and the right weather, gljiva is a synonym for vigorous, unpredictable growth, as in the saying that something or someone "grows like a mushroom [raste ko gljiva]." The edible kinds hide in forests or fields, too easily confused with their poisonous doubles unless one knows better or relies on other experts to tell the difference. They are ideally foraged or received from friends, neighbors, and family. Otherwise they are bought from foragers in precious bundles. On the other hand, stories of fatal fungal poisoning resurface each season, and the medical staff of the clinic for infectious diseases reproaches their patients for daring to eat wild mushrooms, even as they roll in from the ambulance, vomiting and shivering, losing their grip on consciousness. A fear of poisoning keeps some avid collectors from consuming and cautions some cooks to stick to the plainest, farm-harvested, store-bought champignons. Interestingly, fungal toxicity is not a part of the regional imaginaries of the mushrooms that are selectively repurposed and redirected to take new form as a medicinal pseudo-mushroom in a jar. Whereas gifting in Bosnia is typically a precarious affair, demanding a tactful steering away from insulting and hurting, smuggling in irrevocable, reciprocal debts (see Jasarevic 2012), poison is not readily suspected in the mushroom gift. 
Anna Tsing (2012, 141) prompts us to "consider mushrooms.” She finds fungi thriving in symbiotic associations, huddled "defensively in neglected margins," and spreading through accidents and interrelationships, not always benign. With other species mushrooms grow largely outside the schemes of domestication, they are the unearned gifts of a local, ecological bounty or unintended escorts to human ventures, from colonial seafaring to radioactive contamination (Tsing 2012, 149, 151). While the history of grain production mythologizes human independence from other species and clearly inscribes private property and specific purposes to the land, the mushrooms' growing and foraging takes place in diverse landscapes, companionate relations, and overlapping sovereignties. In short, mushrooms, according to Tsing $(2012,141,151)$, model the universal nature of interspecies relation and sustain a different economy, be it of foraging or global commercial mushroom picking. They afford a critical insight into associative possibilities and biological diversity at the unruly edges and in the seams of what, I think, Tsing here means by "an empire": manifold, historically wielded forms of domestication and discipline of the biological species, framed by persuasive property relations that confine love and care to family while prescribing economic rationality toward strangers.

The medicinal mushrooms in jars, on the other hand, are affecting economic and relational practices from within domestic spaces. Fostered rather than domesticated, the mushrooms are grown with hopes that they will overgrow their humans' bodies and are fed and sent onward, with much optimism, to associates and strangers. And this gesture onward - a gifting forth of a surplus - is itself endorsed by the mushrooms' giving nature.

Importantly, the mushroom in this corner of the Balkans is not only a (micro-) organic, fungi-bacterial form but also a collective, sustained fiction, signed with jest - :D. The fictive form of the mushroom provides cultivators with a handle on the biotic companions but does not decisively steer a relational imagination toward the thing itself. Nor is this a sensible kind of wonder packed in a handy commodity form that demands no contemplation beyond consumption: choosing the right flavor for the right price or favoring a brand. Rather, how to properly attend to the mushrooms was an ongoing problem, constantly pondered and collectively tackled. There is plenty of advice on reading mushrooms' moods and states: is it healthy when it "floats" or "sinks"; is it "sick" when the grains are overly slimy, and how then to cure it? The cultivators shift between registers of familiar relations - human to human, human to plant or animal, being to being in general - considering and recommending suitable forms: "It is alive"; "treat it 
as any other living being”; “it's another member of your household"; and, a kindred post: "if there is no two-legged company nearby, dance with your bacteria." 21 The author neither says nor knows how you could disco with the microbes, and I want to read his unfinished prompt as more than being cute: it registers buoyancy (the "racing acids" of real-speak) that is not simply human but coauthored by a human-animal-biotic-fungal digestive embrace.

The handling problem recurs, rehearsing the unresolved questions: What is the object of contact and a form of connection? How do you touch the mushroom to preserve its vitality and potency or, indeed, to please it: immediately, fingers to its body, or through intermediaries, and then of what kind? Warnings about touching include suggestions to "gently massage" the kefir grains, "which, according to some, like to be patted." 22 Related is the question of cultures' cleansing. One Alan asserts that "washing is torture for the [kefir] grains. They have to contaminate milk with their bacteria and yeast." ${ }^{23}$ Contagion is courted and the production is thoroughly caught up in the care of the undecided aliveness in the jar.

Whatever it may be in the jar, it is earnestly made up as the mushroom. A microbiologist would tell us that the yeast in the symbiotic composition of the mushrooms is, in fact, a fungal organism and that mushrooms are associated microbes made visible to the eye. But I am not interested in establishing a formal symmetry between the vernacular and the microbiological take on the things in the jar. My point is neither that popular stories about nature are meaningful if there exist poetic flourishes to the real, microbiotic composition of the thing, nor that, essentially, nothing substantial exists but, à la Bruno Latour, that we find only exteriority of horizontal, natural-cultural actants assembling and reassembling, all on the surface, into black boxes or propositions. Rather, the fiction of the fungus, the yeast, and the bacteria, the delicate influences of the surroundings, and the many clues about the stuff in the jar-giving, excessive, accidental, spirited, wondrous - effectively, logistically, and inconclusively make up this therapeutic thing, which, whatever else it is, is fermenting. Fermentation brings up from obscurity a fizzy potential, a curative promise, a relational riddle, putting the cultivators to work, to share, to ponder.

Things fermenting are especially effectual. While the jars themselves enjoy eventful careers of recycling, the stuff inside them is more intensely alive. It is both original, issuing forth, and historical, having arrived from places, with traces, known and mythical. It manifests being as obviously plural: composed of grains, folds, and microbes, responding to many names and ailments. It models prom- 
issory potencies, mostly undisclosed, of an agent capable of interacting in infinitely varied ways, depending on the singular consuming-cultivating bodies and landscapes of circulation. It stimulates practically philosophical speculations, not always explicit but proposed and tested in the course of fungal-human coconsumption. The inquiries are conceivable only because the bodily capacity of the mushroom-minding humans is as unresolved as the matter of the mushrooms, and so their natures are substantially worked and worked out through trials. I want to insist on the widely consequential power of amateur trials and on forms of guessing and knowing that are elaborate or enchanted rather than experimentally sensible. In other words, my challenge is to think with things that are logistically hyperactive, socially voracious, therapeutically potent, and not just vague but other than what they are said to be-mushrooms - while analyzing, all along, how they matter and what matters to them, from guts to utensils, from borders to the relational imaginations of their hosts. Home trials and practical inquiries, as well as the playful pretense about the mushroom, play out in the domain that Stengers $(2003,23)$ calls "imagination" and that she wants to reclaim from the stock of forces and attributes suspected by rational medicine in its struggle against charlatans and treacherously susceptible bodies. Imagination, Stengers suggests, is a vital responsiveness of all living organisms that can be neither predicted nor controlled for. Since mushrooms and humans respond to each other differently but insistently, cuing the interventions and improvisations, shaping experiences and effects, imagination stirs the very flesh of the things in the jar, which remains essentially unsettled, and keeps bubbling.

\section{IN CONCLUSION: Banal Efficacies}

The mushrooms in the jars prompt us to think more playfully with and about the kinds of things that exist, affect, and inspire wonder, that are cultivated and made up broadly across social spaces and, particularly, in post-Yugoslav terrains. Home fermentation rings, online and on the ground, span the region, transformative and transactional. They nurture and distribute mushroom jars with a reverence for the regional tradition of domace foods and medicine. If the lively jars are abandoned by the state and capital, they are also found, and doubly so: discovered by chance, through advertisements and other people's offerings. They are established and tended with devotion as a preferred course of medical and economic action. The mushroom tenderly translates alien forms to the more familiar strangeness of the uncontained vitality, which figures and cues anew the perennial problem of being social. The fictive fungus precisely trespasses the 
affective limits of the home economy or of some default (species, ethnic, or national) collective. They mobilize their cultivators around issues of health care, but in so doing, they nurture extensions across post-Yugoslav regions in manners not anticipated by more formal visions of postconflict cooperation. Sometimes glossed as the "Yugosphere," ${ }^{24}$ the understated economic relationships between the former Yugoslav states are either condemned as nostalgic and politically reactive or credited with a political promise of facilitating integration and the region's accession to the European Union. The ontologically speculative biotic collectives are busy outside this model of economic pragmatism, but they are economizing, gifting, and distributing surpluses, wielding considerable power without an overly ambitious project. They are not isolated examples of useful, ground-level exchanges between the former states, but are remarkably intimate, given the consensus on the gift and the swaps of delicate traces of bodily and kitchen ecologies. Favoring banal effects over ethnonational matters, pursuing obscure natures rather than multiethnic essences, they intervene in matters of being and experience, affecting life-forms and gathering subjects, practically minded and invested in bodies and therapeutic objects. What gathers them, however, are new and thrilling forms of being together that claim attention, urge generous action, and ferment the imagination around the abundance of unlikely things.

\section{ABSTRACT}

This essay thinks with things that ferment medical remedies in recycled jars and issue exuberant surpluses across kitchens in Bosnia and ex-Yugoslavia. While the jars are handled under the preferred sign of the mushroom and brewing recipes include instructions on non-commercial exchange, the nature of the things in the jar remains vague. Brewing in the kitchens and circling as gifts are buoyant life-forms that alter their hosts, inspire zones of unexpected connection and relational innovation, and direct home trials and ontological speculations around some burning, practical questions: How best to relate to the mushroom? With whom should one relate via the mushroom, and how? The texts explores the fungal materialities and pluripotencies with an ear for popular experiments, teasing out the banal as well as charmed interplay between imagination and association, knowledge and experience. I join the conversation on new materialisms and step into spaces of being and relating across formal differences, but do so in the idiom of kitchen fermentations rather than multispecies or multiethnic relations to attend to the kinds of things that act and inspire wonder outside ready-made rubrics and analytics. [ontologies; mushrooms; politics of things; popular medicine; efficacy; exchange] 


\section{NOTES}

Acknowledgments I offer my sincere thanks to many people who exercised their patience, imagination, and editing talents on this piece. Thanks especially to Caryn O'Connell, Aleksandr Prigozhin, Owen Kohl, Andy Graan, Larisa Kurtovic, Jim Hevia, Michele Rivkin-Fisch, and Erin Koch. Judy Farquhar, as ever, inspired. A grateful nod to my fermentation teachers across Bosnia, as well as to the participants of the 2014 SOYUZ (Research Network for Postsocialist Cultural Studies) conference who tasted the kefir: jointly they showed the way to truly thinking with things. In Bosnia, Slavica Ibrisimovic, Mirza Muftic, Azra Jasarevic, and my parents got exceedingly involved with the mushroom and sustained this project; without Nerka, however, the mushrooming affairs would have turned tragic. Finally, my deepest thanks to Cultural Anthropology's anonymous readers, the editorial team, and most of all, to the generous and insightful Cymene Howe - without all of you, this would have been simply a nice try.

1. Oraščić, in conversation thread "Kefir," Forum.hr, May 2, 2009, http://www.forum.hr/ showthread.php?t=452470.

2. Sminka95, in conversation thread "Tibetanska Gljiva i Spas u Njoj" [Tibetan mushroom and cure within it], Alternativno Liječenje-Vutra Organizacija, March 6, 2013, https:// www.vutra.org/topic/10132-tibetanska-gljiva-i-spas-u-njoj/.

3. “Čajne Gljive” [Tea mushrooms], Cvijet.Info.Forum, http://www.cvijet.info/forum/forum_posts.asp?TID=5054\&title $=$ ajne-gljive.

4. Isabelle Stengers's (2010, 3-19) contribution, however, is concerned more broadly with nonhumans and especially those without experimental validation, the designated creatures of imagination. Also, Bennett's (2010, 35-63) attention spans literature as well as roadside trash, but the speculative onto-stories she presents are mostly of her own making, which is a strategy that poses different theoretical risks than the ethnographer's. Similarly with Hawkins: while he is interested in domestic trash, plastic bags more specifically, his proposed re-enchantment of plastics' agential and affective potentials are framed by the "we," which is the source of Hawkins's $(2010,119-39)$ insights: Euro-American consumers and recyclers, with a shared if not consensual sense of environmental guilt and consciousness.

5. Most cited in English are books by Gunther Frank (1995) and Sandor Katz (2003), as well as the website Kefir!, http://users.sa.chariot.net.au/dna/kefirpage.html. Among many online sources in Italian and Spanish, the following two are typical: Giuseppe Limido, "Kombucha," chapter 3 of "Prevenzione e cura del cancro in Medicina Naturale e Alternativa" [Prevention and treatment of cancer in natural and alternative medicine] (thesis, Istituto Riza, Milan, 2007), http://www.giuseppelimido.com/wp-content/uploads/2012/02/CAP.-3_Il-Kombucha_pag-78-110.pdf; and "Fermentación: ¿Qué demonios es la kombucha?" [Fermentation: What the hell is Kombucha?], Eva Muerde La Mongana, May 8, 2013, http://www.evamuerdelamanzana.com/2013/05/fermentacion-que-demonios-es-la-kombucha. Online texts also cite a handful of academic publications on the results of medical trials of kombucha, Tibetan mushroom, and dairy kefir. Most cited are papers by Maalouf, Baydoun, and Rizk (2011) and by Diniz, Garl, Schneedorf, and Carvalho (2002).

6. World Health Organization, "Bosnia and Herzegovina: Country Cooperation Strategy at a Glance," April 2007, http://www.who.int/countryfocus/cooperation_strategy/ ccsbrief_bih_en.pdf.

7. Anita Supe, “Tibetanska Gljiva Koja To Nije," [Tibetan mushroom which isn't], posted in blogspot Istine i Laži o Hrani, http:/ /istineilaziohrani.blogspot.com.

8. Harka, “Moja Žučna Kesa Nakon Tibetanske Gljivice,” Coolinarka, December 9, 2010, http://www.coolinarika.com/slika/435334/.

9. Duskoo, in a conversation thread "Tibetanska Gljiva, Dijabetes" [Tibetan mushroom, diabetes], Doktor.rs Forum, October 7, 2005, http://www.doktor.rs/forum/dijabetes/ tibetanska-gljiva-t3198.html. 
10. Dr. Ivica Zdravkovic, in a conversation thread "Tibetanska Gljiva, Dijabetes," Doktor.rs Forum, July 26, 2006, http://www.doktor.rs/forum/dijabetes/tibetanska-gljivat3198.html.

11. Iskra, “Kombucha_Ljekovita Čajna Gljiva," Slobodni.net, March 18, 2011, http:// slobodni.net/t61051/. Ronald Reagan is mentioned in the English web sources about Kombucha as well.

12. "Tibetanska Gljiva i Spas u Njoj" [Tibetan mushroom and cure within it], Alternativno Liječenje- Vutra Organizacija, March 6, 2013, https://www.vutra.org/topic/10132tibetanska-gljiva-i-spas-u-njoj/; see also Niandeka, in conversation thread "Kombuchaljekovita gljiva” [Kombucha - medicinal mushroom], Magicus.info Magazin, n.d.

13. Senad Causevic, comment on "Kefir-Ljekovita Gljiva sa Kavkaza" [Kefir -medicinal mushroom from the Caucuses], Alternativa za Vas, March 12, 2012. Zorana, comment on "Kefir-Ljekovita Gljiva sa Kavkaza" [Kefir -medicinal mushroom from the Caucasus], Alternativa za Vas, March 12, 2012, http://alternativa-za-vas.com/index.php/clanak/ article/kefir.

14. Stipo Popic, "Tibetanska Gljiva-Lijeci sve moguce bolesti organizma," in response to Anonimno's blog comment, Savjeti za Zdrav Zivot i Ljekovito Bilje, November 13, 2012, http://www.ljekovitasvojstvabiljaka.blogspot.com/2012/02/tibetanska-gljiva-lijecisve-moguce.html.

15. Popic, "Tibetanska Gljiva."

16. Zak Srem and Martina, in conversation thread "Tibetanska Gljiva Koja to Nije" [Tibetan mushroom which isn't], blogspot Istine i Laži o Hrani [Truths and lies about food], April 3, 2013; June19, 2013, http://istineilaziohrani.blogspot.com.

17. See The Kombucha Journal, www.kombu.de.

18. "At a tender age of 15 " in the case of the founder of GT's Kombucha, GT Dave: a genius. See "A Message from GT," GT's website, http://synergydrinks.com/index. php/our-story/\#a-message-from-gt.

19. “The 21st Century Kombucha Debate: Pasteurized vs. Raw,” November 16, 2010, Kombucha Wonder Drink, http://www.wonderdrink.com/news/kombucha-raw-vspasteurized/.

20. Jennifer Cirillo, "Wonder World: Kombucha Wonder Drink Intrigues Consumers and Has Cemented Its Place in a Niche Category,” Beverage World, June 6, 2013, http:// www.wonderdrink.com/wp-content/uploads/2013/07/page2-BeverageWorldJune2013-WONDER_WORLD1.pdf.

21. Papa Romeo in conversation thread "Tibetanska Gljiva i Spas u Njoj” [Tibetan mushroom and cure within it], Alternativno Liječenje — Vutra Organizacija, March 6, 2013, https:// www.vutra.org/topic/10132-tibetanska-gljiva-i-spas-u-njoj. The last quote came from a post on the Magicus.info forum, which has since been erased. The forum still archives some Kombucha articles and conversations. See, for instance, Rea's post on "Ljekoviti Napitak od Tibetanske "Kombuche," [Curative beverage of Tibetan kombucha], Magicus.Info, September 14, 2010, http://www.magicus.info/hr/magicus/tekst.php?id= 53860 .

22. MarcoPolo in a conversation thread "Tibetanska Gljiva i Spas u Njoj” [Tibetan mushroom and cure within it], Alternativno Liječenje—Vutra Organizacija, March 6, 2013, https:// www.vutra.org/topic/10132-tibetanska-gljiva-i-spas-u-njoj/.

23. Alan_SP, in a conversation thread "Kefir," Forum.hr, March 31, 2009, http:// www.forum.hr/showthread.php?t $=452470$.

24. Tim Judah coined the term in 2009 in an article for The Economist.

\section{REFERENCES}

Bennett, Jane

2009 Vibrant Matter: A Political Ecology of Things. Durham, N.C.: Duke University Press.

2010 “Thing-Power.” In Political Matter: Technoscience, Democracy, and Public Life, edited by Bruce Braun and Sarah Whatmore, 35-63. Minneapolis: University of Minnesota Press. 
Bogost, Ian

2012 Alien Phenomenology, or What It's Like to Be a Thing. Minneapolis: University of Minnesota Press.

Bougarel, Xavier, Elissa Helms, and Ger Duijzings

2007 The New Bosnian Mosaic: Identities, Memories and Moral Claims in a Post-War Society. Burlington, Vt.: Ashgate.

Braun, Bruce, and Sarah J. Whatmore

2010 "The Stuff of Politics: An Introduction." In Political Matter: Technoscience, Democracy, and Public Life, edited by Bruce Braun and Sarah J. Whatmore, ix-

Caldwell, Melissa xl. Minneapolis: University of Minnesota Press.

2004 Not by Bread Alone: Social Support in the New Russia. Berkeley: University of California Press.

2010 Dacha Idylls: Living Organically in Russia's Countryside. Berkeley: University of California Press.

2014 "Gardening for the State: Cultivating Bionational Citizens in Postsocialist Russia." In Ethical Eating in the Postsocialist and Socialist World, edited by Yuson Jung, Jakob Klein, Melissa Caldwell, 188-210. Berkeley: University of California Press.

Cirillo, Jennifer

2013 "Wonder World.” Beverage World Magazine, June, 41.

Daston, Lorraine, ed.

2000 Biographies of Scientific Objects. Chicago: University of Chicago Press.

Derrida, Jacques

1994 Specters of Marx: The State of Debt, the Work of Mourning, and the New International. New York: Routledge.

Diniz, Douglas Teles, Jose Mauricio Schneedorf, and Jose Carlos Carvalho

2002 "Study of Anti-Inflammatory Activity of Tibetan Mushroom, a Symbiotic Culture of Bacteria and Fungi Encapsulated into a Polysaccharide Matrix." Pharmacological Research 47, no. 1: 49-52. http://dx.doi.org/10.1016/S1043-6618(02)002402 .

Dunn, Elizabeth

2008 "Postsocialist Spores: Disease, Bodies, and the State in the Republic of Georgia." American Ethnologist 35, no. 2: 243-58. http://dx.doi.org/10.1111/j.15481425.2008.00032.x.

Frank, Gunther

1995 Kombucha: Healthy Beverage and Natural Remedy from the Far East. Steyr: Ennsthaler Gesellschaft MBH \& CO.

Harman, Graham

2005 Guerrilla Metaphysics: Phenomenology and the Carpentry of Things. Chicago: Open Court Publishing.

Heidegger, Martin

1971 “The Thing.” In Poetry, Language, Thought, 163-80. New York: Harper \& Row. Ingold, Tim

2006 "Rethinking the Animate, Re-Animating Thought." Ethnos: Journal of Anthropology 71, no. 1: 9-20. http://dx.doi.org/10.1080/00141840600603111.

Jansen, Stef, Črna Brković, and Vanja Č Celebčić

Forthcoming Negotiating Socialities in Bosnia and Herzegovina. Burlington, Vt.: Ashgate. Jasarevic, Larisa

2012 "Grave Matters and the Good Life: On a Finite Economy in Bosnia." Cambridge

Katz, Sandor Ellix Anthropology 30, no. 1: 25-39. http://dx.doi.org/10.3167/ca.2012.300104.

2003 Wild Fermentation. The Flavor, Nutrition, and Craft of Live-Culture Foods. White River Junction, Vt.: Chelsea Green.

2006 The Revolution Will Not Be Microwaved: Inside America's Underground Food Movement. White River Junction, Vt.: Chelsea Green. 
Kurtovic, Larisa

2013 "Politics of Impasse: Specters of Socialism and the Struggles for the Future in Postwar Bosnia-Herzegovina." PhD dissertation. University of California, Berkeley.

Langwick, Stacey

2011 Bodies Politics, and African Healing: The Matter of Maladies in Tanzania. Bloomington: Indiana University Press.

Latour, Bruno

1988 Science in Action: How to Follow Scientists and Engineers Through Society. Cambridge, Mass.: Harvard University Press.

2005 Reassembling the Social: An Introduction to Actor-Network Theory. Oxford: Oxford University Press.

Maalouf, Katia, Elias Baydoun, and Sandra Rizk

2011 "Kefir Induces Cell-Cycle Arrest and Apoptosis in HTLV-1-negative Malignant T-lymphocytes." Cancer Management and Research 3:39-47. http://dx.doi.org/ 10.2147/CMR.S15109.

Marchart, Oliver

2007 Post-Foundational Political Thought: Political Difference in Nancy, Lefort, Badiou, and Mijatović, Jova Laclau. Edinburgh: Edinburgh University Press

1982 Travar. Trave i Melemi. Beograd: Porodica i Domaćinstvo.

Morton, Timothy

2013 Hyperobjects: Philosophy and Ecology after the End of the World. Minneapolis: University of Minnesota Press.

Munn, Nancy

1986 The Fame of Gawa: A Symbolic Study of Value Transformation in a Massim Society. Nancy, Jean-Luc Cambridge: Cambridge University Press.

1991 The Inoperative Community. Minneapolis: University of Minnesota Press.

Paxson, Heather

2008 "Post-Pasteurian Cultures: The Microbiopolitics of Raw-Milk Cheese in the United States.” Cultural Anthropology 23, no. 1: 15-47. http://dx.doi.org/10. $1111 /$ j.1548-1360.2008.00002.x.

2013 The Life of Cheese: Crafting Food and Value in America. Berkeley: University of California Press.

Pelagić, Vaso

1972 Narodni Ucitelj. Beograd: Sloboda.

Rivkin-Fish, Michele

2005 "Bribes, Gifts and Unofficial Payments: Rethinking Corruption in Post-Soviet Russian Health Care.” In Corruption: Anthropological Perspectives, edited by Dieter Haller and Chris Shore, 47-65. London: Pluto Press.

Sadiković, Sadik

1988 Narodno Zdravlje. Svjetlost: Sarajevo.

Silverman, Chloe

2012 "Desperate and Rational: Of Love, Biomedicine, and Experimental community." In Lively Capital: Biotechnologies, Ethics, and Governance in Global Markets, edited by Kaushik Sunder Rajan, 354-85. Durham, N.C.: Duke University Press.

Stengers, Isabelle

2003 “The Doctor and the Charlatan." Cultural Studies Review 9, no. 2: 11-37. http:// dx.doi.org/10.5130/csr.v9i2.3561.

2010 “Including Nonhumans in Political Theory: Opening Pandora's Box?" In Political Matter: Technoscience, Democracy, and Public Life, edited by Bruce Braun and Sarah J. Whatmore, 3-35. Minneapolis: University of Minnesota Press. 
Tsing, Anna

2012 "Unruly Edges: Mushrooms as Companion Species." Environmental Humanities $1: 141-54$.

Wagner, Sarah

2008 To Know Where He Lies: DNA Technology and the Search for Srebrenica's Missing. Berkeley: University of California.

Yatova, Maria

2013 “'It is the Bacillus that Makes Our Milk': Ethnocentric Perspectives on Yogurt in Postsocialist Bulgaria." In Why We Eat, How We Eat: Contemporary Encounters Between Foods and Bodies, edited by Emma-Jayne Abbots and Anna Lavis, 16986. Aldershot: Ashgate. 